\title{
BIOTECHNOLOGICAL ASPECTS \\ OF WASTEWATER TREATMENT OF ENTERPRISES THAT PROCESS LIVESTOCK PRODUCTS
}

\author{
P. Rebrykova, O. Shydlovska, N. Zholobak, O. Mokrousova \\ Kyiv National University of Technologies and Design
}

\begin{tabular}{|c|c|}
\hline Key words: & ABSTRACT \\
\hline $\begin{array}{l}\text { Biotechnology } \\
\text { Wastewater } \\
\text { Organic contamination } \\
\text { Purification } \\
\text { Immobilized } \\
\text { microorganisms } \\
\end{array}$ & $\begin{array}{l}\text { The article deals with the problem of deterioration of the } \\
\text { environment due to the presence of highly concentrated con- } \\
\text { taminated with organic compounds of wastewater at proce- } \\
\text { ssing plants livestock products. It is determined that the } \\
\text { problem of wastewater treatment has not only an ecological } \\
\text { background, but also is related to the inefficient work of the }\end{array}$ \\
\hline $\begin{array}{l}\quad \text { Article history: } \\
\text { Received } 12.11 .2018 \\
\text { Received in revised form } \\
05.12 .2018 \\
\text { Accepted } 20.12 .2018\end{array}$ & $\begin{array}{l}\text { wastewater treatment plants itself, due to the use of outdated } \\
\text { technologies and the equipment. The analysis of literary data } \\
\text { on the main characteristics of wastewater at these enter- } \\
\text { prises, existing methods of their purification are carried out. } \\
\text { It has been found out that traditional methods using aero }\end{array}$ \\
\hline $\begin{array}{l}\text { Corresponding author: } \\
\text { P. Rebrykova } \\
\text { E-mail: } \\
\text { npnuht@ukr.net }\end{array}$ & $\begin{array}{l}\text { tanks cannot meet the necessary indicators of wastewater } \\
\text { treatment. The advantages of the biological method of } \\
\text { wastewater treatment, conditions, and requirements for its } \\
\text { use are considered. A number of problems are found which } \\
\text { are solved with the involvement of associations of micro- } \\
\text { organisms. Well known effective associations of microorga- } \\
\text { nisms that are immobilized on the carrier for the purpose of } \\
\text { obtaining biomass that directly participates in the purifi- } \\
\text { cation process are described. But at high pollution rates it is } \\
\text { proposed to intensify the processes of biological purification } \\
\text { by transferring the treatment plant to the biosorption regime, } \\
\text { which increases the efficiency of cleaning by increasing the } \\
\text { concentration of active sludge when introducing carriers } \\
\text { with immobilized microorganisms. } \\
\text { Examples of modifications of technology in which the } \\
\text { parameters of immobilization of microorganisms, the regime } \\
\text { of air intake change, are indicated, the expediency of using a } \\
\text { certain selected kind of microorganisms and their combina- } \\
\text { tion with other types of biological agents are indicated. } \\
\text { It has been established that the advantages of this method } \\
\text { are low cost and environmentally friendliness, since the utili- } \\
\text { zation technologies do not require significant structural changes } \\
\text { to existing wastewater treatment lines, and as a carrier, it is } \\
\text { possible to use various wastes of natural and artificial origin. }\end{array}$ \\
\hline
\end{tabular}

DOI: $10.24263 / 2225-2924-2018-24-6-7$ 


\title{
БІОТЕХНОЛОГІЧНІ АСПЕКТИ ОЧИЩЕННЯ СТІЧНИХ ВОД ПІДПРИЕМСТВ, ЩО ПЕРЕРОБЛЯЮТЬ ПРОДУКТИ ТВАРИННИЦТВА
}

\author{
П.А. Ребрикова, О.А. Шидловська, Н.М. Жолобак, О.Р. Мокроусова \\ Київський наиіональний університет технологій та дизайну
}

У статті розглянуто проблему погіршення становища навколишнього середовища через наявність висококонщентрованих, забруднених органічними сполуками стічних вод на підприємствах, щео переробляють продукти тваринництва. Визначено, що проблема очищення стічних вод має не тільки екологічне підтрунтя, але також зумовлена неефективною роботою самих очисних споруд, оскільки використовуються застарілі технології, а обладнання є зноченим. Проведено аналіз літературних даних щодо основних характеристик стічних вод таких підприємств, існуючих методів їх очищення.

3'ясовано, що традииійні методи з використанням аеротенків не можуть задовольнити необхідні показники очищення стічної води. Розглянуто переваги біологічного методу очищення стічних вод, умови та вимоги до його використання. Виявлено ряд проблем, які вирішуються при залученні асоиіачій мікроорганізмів. Охарактеризовано відомі ефективні асоиіації мікроорганізмів, які іммобілізують на носії з метою збільшення біомаси, яка безпосередньо бере участь в процесі очищення. При високих показниках забруднення запропоновано інтенсифікувати процеси біологічного очищення иляхом переведення очисної споруди в режсим біосорбиії, щьо підвищує ефективність очищення за рахунок збільшення конщентращії активного мулу при введенні носіїв з іммобілізованими мікроорганізмами.

Наведено приклади модифікаиій технології, в яких змінюються параметри іммобілізації мікроорганізмів, режим надходження повітря, вказано на доцільність використання певних підібраних родів мікроорганізмів та їх поєднання з іншими видами біологічних агентів.

Встановлено, щзо перевагами даного методу є дешевизна та екологічність, оскільки технологї утилізації не вимагають суттєвих конструкційних змін вже існуючих ліній очищення стічних вод, а як носії можна використовувати різноманітні відходи природного та штучного походження.

Ключові слова: біотехнологія, стічні води, органічне забруднення, очищення, іммобілізовані мікроорганізми.

Постановка проблеми. Сільськогосподарське виробництво є однією із ключових галузей вітчизняної економіки, забезпечуючи дешевою та якісною сировиною харчові, фармацевтичні, шкіряні та інші підприємства України. Процеси обробки такої сировини вимагають залучення великих водних ресурсів, що впливає на стан екосистеми навколишнього середовища. Ситуація погіршується через неефективну роботу очисних споруд, що обумовлено 
застарілими технологіями очищення стічних вод і зношеністю самого обладнання. Слід зазначити, що санітарно-гігієнічні умови на тваринницьких фермах також в основному підтримуються за допомогою води. Ї̈̈ використовують для миття тварин, очищення приміщень та їх дезінфекції, підготовки кормів, миття посуду й апаратури, гідрозмиву гною тощо. В середньому, кількість стоків тваринницьких комплексів коливається від 250 до 3000 тонн на добу (від 90 тис. до 1 млн тонн на рік). Тобто стан водних об'єктів постійно погіршується внаслідок скидання неочищених і недостатньо очищених стічних вод. У зоні тваринницьких комплексів основними екологічними проблемами $\epsilon$ евтрофікація водойм, нагромадження патогенних мікроорганізмів, забруднення атмосферного повітря сірководнем, аміаком, молекулярним азотом та іншими сполуками.

Слід зазначити, що проблема очищення стічних вод пов'язана з вирішенням не тільки природоохоронних, а й низки техніко-економічних і технологічних завдань, оскільки ситуація погіршується через неефективну роботу очисних споруд, що обумовлено застарілими технологіями очищення стічних вод і зношеністю самого обладнання. Оскільки більшість каналізаційних очисних споруд України збудовані в 60-70-их роках XX ст. та не передбачали видалення біогенних елементів (тоді їх концентрація в стічних водах була на порядок нижче), одним із ефективних сучасних методів підвищення ефективності очистки стічних вод $є$ реконструкція діючих каналізаційних очисних споруд, що включатиме суттєву інтенсифікацію їх роботи.

Метою статті $\epsilon$ обгрунтування біотехнології обробки стічних вод тваринництва 3 використанням біологічних методів для підвищення ефективності вилучення органічних забруднюючих речовин та доведення якості очищених стічних вод до чинних нормативів.

Викладення основних результатів дослідження. Відомо, що в сучасних наукових дослідженнях пріоритет надається використанню не тільки екологічних, але й економічно рентабельних методів обробки й утилізації відходів. $\mathrm{y}$ цьому контексті запропоновано повторне використання стічних вод тваринництва як технічної води на підприємстві, води для зрошення полів, а також використання осадів як основи для компосту. Але в такому разі стічні води мають відповідати ряду вимог [1], оскільки вони містять різноманітні залишки органічних речовин, а кількість патогенної мікробіоти перевищує гранично допустимі норми. Характеристика стічних вод наведена в табл. 1.

Табличя 1. Характеристика стічних вод підприємств, що переробляють продукти тваринництва [2]

\begin{tabular}{|c|c|}
\hline Показники & Діапазон \\
значень показників
\end{tabular}


3 усіх відомих методів очищення промислових стічних вод найбільш реальну перспективу до впровадження мають ті, що передбачають використання вже існуючих споруд та обладнання, з їх доопрацюванням або модифікацією параметрів роботи. При високих навантаженнях за забрудненням на очисні споруди одним із раціональних способів $є$ біологічне очищення як один з головних етапів очистки.

Суть біологічного очищення полягає в біохімічному окисленні органічних речовин мікроорганізмами. Для нормального процесу синтезу речовин у клітині, а отже, й ефективного очищення стічної води, у водному середовищі повинна бути достатня концентрація всіх основних елементів живлення — карбону, вміст якого, зазвичай, характеризується величиною біологічно споживаного кисню (БСК), нітрогену i фосфору, співвідношення яких має становити: БСК: азот:фосфор - 100:5:1. При цьому ступінь їх видалення із стічних вод в оптимальних умовах $\left(t=25-30^{\circ} \mathrm{C}, \mathrm{pH}=6,5-7,5\right.$, вказане співвідношення біогенних елементів, відсутність токсичних для мікроорганізмів речовин) становить до $90 \%$.

Привабливість цього методу полягає в унікальній здатності мікроорганізмів адаптуватися до вкрай несприятливих умов навколишнього середовища. За рахунок використання асоціацій мікроорганізмів вирішуються такі питання:

- зменшення показників забруднень до встановлених гранично-допустимих норм скиду у водойми;

- відпрацьований активний мул вміщує велику кількість елементів живлення, що дає змогу використовувати його як добриво після попередньої обробки в метантенках присутності патогенної мікрофлори);

- можливе отримання біогазу, за умови використання метантенків, як додаткового джерела палива (утворений газ можна використовувати для підігрівання води та опалення цехів підприємства).

- при одержанні біогазу без доступу повітря перероблюваний гній повністю зберігає азот в органічному добриві (тоді як при його компостуванні майже половина азоту втрачається), що підвищує ефективність його використання в сільському господарстві;

- забезпечується екологічність очищення стічних вод без додаткового використання хімічних реактивів (отримані продукти $є$ повністю засвоюваними природними біоценозами, підтримується колообіг поживних речовин).

Однак при надто високих забрудненнях традиційні методи з використанням аеротенків не завжди можуть задовольнити необхідні показники очищення стічної води підприємств тваринництва. Тому пропонується інтенсифікація процесів біологічного очищення за рахунок введення носіїв з іммобілізованими мікроорганізмами [3; 4]. Доведено, що такі гідробіонти є більш стійкими та ефективними порівняно з вільно плаваючим активним мулом.

В останні роки за допомогою нових молекулярно-біологічних методів в активному мулі виявлено бактерії родів Paracoccus, Caulobacter, Hyphomicrobium, Nitrobacter, Acinetobacter, Sphaerotilus, Aeromonas, Pseudomonas, Cytophaga, Flavobacterium, Flexibacter, Halisomenobacter, Artrobacter, Corynebacterium, 
Microtrix, Nocardia, Rhodococcus, Bacillus, Clostridium, Lactobacillus, Staphylococcus. Вважається однак, що натепер ідентифіковано не більше 5\% видів мікроорганізмів, що беруть участь в аеробному очищенні води. Слід зазначити, що багато аеробних бактерій $\epsilon$ факультативними анаеробами. Продуктами їх життєдіяльності є вуглекислота, водень, органічні кислоти і спирти.

Численні дослідження очищення стічних вод у реакторах з мікрофлорою, іммобілізованою на інертних носіях, показують, що процес біодеструкції забруднення триває в декілька разів швидше, ніж в інших типах реакторів [5-9].

Так, автори статті [5], розглядаючи шляхи використання мікроорганізмів, акцентують увагу на їх іммобілізації, як важливій складовій, що забезпечує покращення показників очищення стічних вод. Показано, що біоремедіація стічних вод з використанням мікроорганізмів і їх агрегатів визнана ефективною зеленою технологією (оскільки має біологічне походження) з відносно низькою вартістю порівняно зі звичайними фізичними і хімічними процесами обробки.

Мікроорганізми можуть використовуватися двома способами:

- пряме змішування вільних мікроорганізмів із стічними водами (поділу між мікроорганізмами і оброблюваними стічними водами немає);

- мікроорганізми, іммобілізовані в матеріалах для фіксації або інкапсульовані в матрицю (існує чітка межа між мікроорганізмами і оброблюваною водою).

Використання саме іммобілізованих або інкапсульованих різним способом мікроорганізмів вважається більш ефективним, ніж застосування вільних клітин, оскільки це призводить до більш високого завантаження біомаси, легшої роботи на межі тверда речовина-рідина, вищої швидкості біодеградації та забезпечення кращої стабільності роботи, суттєвого захисту від токсичних речовин, підвищеної стабільності плазмід у складі іммобілізованих клітин [6].

Як матеріал для фіксації або для іммобілізації мікроорганізмів усередині біореактора розглядається лігноцелюлозна біомаса, кераміка, а також полімери як природного, так і синтетичного походження. Іммобілізовані клітини на таких носіях мають величезний потенціал для очищення широкого спектра забруднюючих речовин, включаючи фенольні сполуки, вуглеводні, пропіонітрил, органічні та неорганічні барвники, N, N-диметилформамід, піридин, бензол, толуол і ксилол (ВТX), важкі метали, а також здатні видаляти зі стічних вод біогенні речовини, такі як азот і фосфор. Однак підкреслюється, що в цій сфері потрібна велика кількість різносторонніх досліджень для розробки систематично інтегрованих технологій і підвищення їх ефективності.

Для очищення сильно забруднених стічних вод, особливо 3 високим вмістом сполук азоту, досліджено ефективність послідовного ряду анаеробних, аноксидних, аеробних процесів біологічного очищення стічних вод з використанням іммобілізованих мікроорганізмів [7]. 3 цією метою в аеробній зоні для кращої аерації іммобілізованих мікроорганізмів пропонується встановлювати напрям руху струменів повітря перпендикулярно напряму руху води, що дає змогу досягти добової окисної потужності за амонійним азотом до $120-130 \Gamma / \mathrm{M}^{3}$. 
Покращити показники очищення можна за рахунок виділення таких родів мікроорганізмів, які якомога краще видаляють необхідний вид забруднення. $\mathrm{y}$ [8] безперервний спосіб біологічного очищення стічних вод проводили в аеробних умовах у біореакторі із шаром іммобілізатора. Виділені із стічних вод бактерії роду Acinetobacter було іммобілізовано на новий тип керамічного носія за допомогою вакуумного методу. В результаті дослідження кількість колонізованих бактерій склала $2,9 \cdot 10^{9} \mathrm{KУО/} \mathrm{г} \mathrm{сухого} \mathrm{керамічного} \mathrm{носія,} \mathrm{що}$ значно пришвидшило процес очищення. Система в середньому змогла усунути більше $82 \%$ вхідної хімічної потреби на кисень протягом 160 діб.

На сьогодні визначено, що гриби також можуть відігравати важливу роль в очищенні стічних вод від органічних забруднень. Дослідження [9] вказує на те, що всі аналізовані параметри забруднення води за умови застосування мікробних композицій для ï очистки є нижчими в експериментальних установках порівняно з контрольними. Тобто і бактерії, і гриби мають здатність очищувати стічні води, хоча і не забезпечують стовідсоткову ефективність видалення токсичних компонентів. Слід зазначити, що серед досліджуваних експериментальних моделей виявлену комбінацію бактерій (Pseudomonas aeruginosa) і грибів (Fusarium oxysporum), яка потенційно працює краще, ніж при використанні їх окремо. Тобто комбінація має синергетичну дію. Поряд 3 цим виявлено ще один позитивний момент: іммобілізована асоціація мікроорганізмів пригнічує утворення біоплівки в споруді під час водоочистки [10]. Підтвердженням перспективності застосування композицій мікроорганізмів $\mathrm{i}$ грибів є результати дослідження [11]. Автори, досліджуючи влив вибраних родів і штамів мікроорганізмів на процес очищення стічних вод, виявили, що ефективність видалення такого біогенного елемента, як фосфор суттєво зростає за умови включення до складу ко-іммобілізованих мікроорганізмів Chlorella spp. та Azospirillum brasilense.

Перевагою біологічного очищення стічних вод $є$ також і те, що як носії можуть використовуватися різноманітні відходи природного та штучного походження, зокрема полімери [12]. На рис. 1 наведено експериментальну установку з волокнистого синтетичного носія, що здешевлює технологію водоочистки та одночасно вирішує низку екологічних проблем.
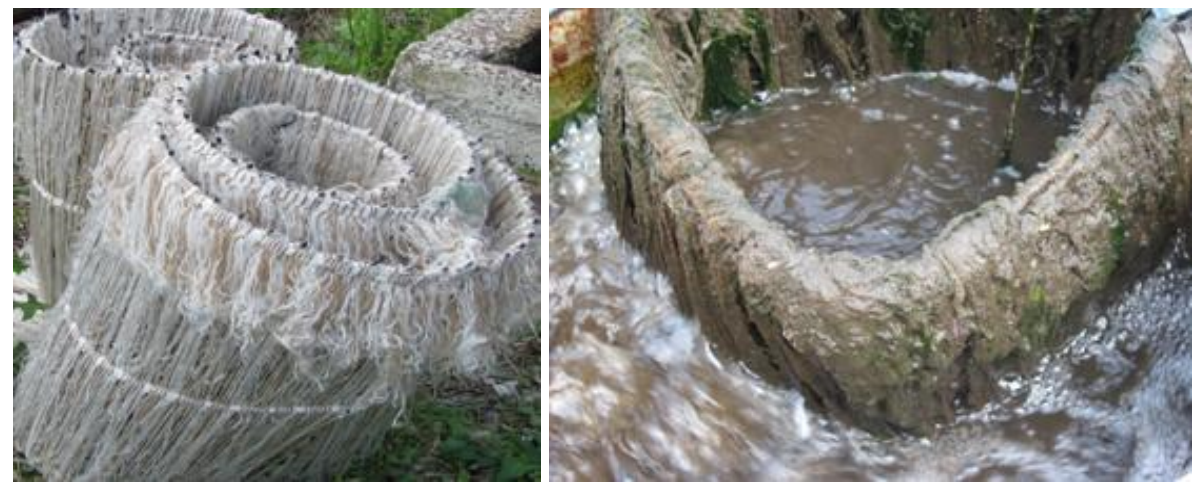

Рис. 1. Носії з іммобілізованими мікроорганізмами [13] 
Так, застосування біологічних препаратів у процесі водоочистки в 510 разів підвищує функціональну ефективність очисних споруд [14].

Отже, метод очищення стічних вод із застосуванням іммобілізованої на інертних носіях мікрофлори не тільки не потребує кардинальної реконструкцій вже існуючих споруд, а й дає можливість покращити якість очищеної стічної води. Варто зауважити, що, порівнюючи з фізико-хімічними, біологічний метод вимагає більшої тривалості очищення води, що, у свою чергу, збільшує час роботи повітродувок та насосної станції.

\section{Висновки}

Визначено основні проблеми обробки стічних вод тваринництва та їх склад. Встановлено, що очищення промислових стічних вод від забруднень органічними сполуками ефективне при використанні біологічного очищення в аеротенках. Процес доцільно інтенсифікувати шляхом переведення очисної споруди в режим біосорбції, що підвищує ефективність очищення за рахунок збільшення концентрації активного мулу.

Технологічно запропонований метод очищення можна реалізувати, попередньо підібравши найбільш ефективні композиції мікроорганізмів, наростивши (іммобілізувавши) їх біомасу на носії окремо від біореактора, в якому безпосередньо відбувається процес очищення. Коректна робота в аеротенку передбачає періодичну заміну чи очистку носіїв від відпрацьованої мікрофлори. Перевагами запропонованого підходу $є$ дешевизна й екологічність, оскільки розглянуті технології утилізації не вимагають суттєвих конструкційних змін вже існуючих ліній очищення стічних вод.

\section{Література}

1. Води стічні та їх осади в тваринництві та птахівництві. Компости на їх основі. Стандарт Мінагрополітики України. СОУ 41.00-37-688:2007. Зареєстровано 29.12.2007, № 1693 (18 арк.). Київ, 2007.

2. Канализация населенных мест и промышленных предприятий / Н.И. Лихачев, И.И. Ларин, С,А. Хаскин и др.; Под общ. ред. В.Н. Самохина. 2-е изд., перераб. и доп. Москва: Стройиздат, $1981.639 \mathrm{c}$.

3. Гвоздяк П.И., Дмитренко Г.П., Куликов Н.И. Очистка промышленных сточных вод прикрепленными микроорганизмами. Химия и технология воды. 1985. Т. 7, № 1. С. $64-83$.

4. Саблій Л.А. Фізико-хімічне та біологічне очищення висококонцентрованих стічних вод: Монографія. Рівне: НУВГП, 2013. 292 с.

5. Das, M., \& Adholeya, A. Potential Uses of Immobilized Bacteria, Fungi, Algae, and Their Aggregates for Treatment of Organic and Inorganic Pollutants in Wastewater. Water Challenges and Solutions on a Global Scale. 2015. URL: sci-hub.tw/10.1021/bk-2015-1206.ch015.

6. Martins S.C.S., Martins C.M., Cidrão Guedes Fiúza L.M., Santaella S.T. Immobilization of microbial cells: A promising tool for treatment of toxic pollutants in industrial wastewater. African Journal of Biotechnology. 2013, 12(28). P.4412-4418.

7. Blyashyna M. Process of biological wastewater treatment for nitrogen, phosphorus removal by immobilized microorganisms. Eastern-European Journal of Enterprise Technologies. 2018. No. 2/10(92). C. $30-37$.

8. Kariminia H.-R., Kanda K., Kato F. Wastewater Treatment with Bacteria Immobilized onto a Ceramic Carrier in an Aerated System. Journal of Bioscience and Bioengineering. 2003. No. 95(2). P. $128-132$. 
9. Arumugam, V., \& Sivakami, R. Treatment of Dye Industry Effluent Using Immobilized Bacteria and Fungi Isolated from Freshwater Pond Thiruvarur District, Tamil Nadu, India. Int. J. Curr. Microbiol. App. Sci. 2016. No. 5(6). P. 596-605.

10. Lee Ch.-H., Lee S.-K., Lee K., Lee S.H., Choi D.-Ch. Container with biofilm formationinhibiting microorganisms immobilized thereon and membrane water treatment apparatus using the same / US 2016/0030890 A1, Pub. Date: Feb. 4, 2016.

11. Hernandez J.-P., de-Bashan L.E., Bashan Y. Starvation enhances phosphorus removal from wastewater by the microalga Chlorella spp. co-immobilized with Azospirillum brasilense Hernandez. Enzyme and Microbial Technology. 2006. No. 38. P. 190-198.

12. Kardena E., Ridhati S.L., Helmy Q. Molecular imprinted hydrogel polymer (MIHP) as microbial immobilization media in artificial produced water treatment / The 4th International Seminar on Sustainable Urban Development IOP Publishing IOP Conf. Series: Earth and Environmental Science 106. 2018. 012088. doi :10.1088/1755-1315/106/1/012088).

13. Бляшина М.В., Саблій Л.А. Технологія та обладнання для анаеробно-аеробного очищення стічних вод. Материалы выставки и конференции «Сотрудничество для решения проблемы отходов». 2012. URL: https://waste.ua/eco/2012/wastewater/treatment/.

14. Бляшина М.В. Енергозбереження в очищенні стічних вод за рахунок анаеробноаеробних процесів. Виробничо-практичний журнал «Водопостачання та водовідведення». Київ, 2011. № 6. С. 55-58. 